\title{
SUM01 wt Allele
}

National Cancer Institute

\section{Source}

National Cancer Institute. SUMO1 wt Allele. NCI Thesaurus. Code C106290.

Human SUMO1 wild-type allele is located in the vicinity of $2 q 33$ and is approximately 32

$\mathrm{kb}$ in length. This allele, which encodes small ubiquitin-related modifier 1 protein, is involved in the post-translational modification of proteins. 